\title{
Back-Translation Technique to Assess the Students' Translation of Literary Text
}

\author{
Rosyidah $^{1}$, M. Kharis ${ }^{2}$, Lilis Afifah ${ }^{3}$ \\ German Department, Faculty of Letters, Universitas Negeri Malang, Malang, Indonesia \\ Email address: \\ rosyidah.fs@um.ac.id (Rosyidah), m.kharis.fs@um.ac.id (M. Kharis), lilis.afifah.fs@um.ac.id (L.Afifah)
}

To cite this article:

Rosyidah, M. Kharis, Lilis Afifah. Back-Translation Technique to Assess The Students' Translation of Literary Text. International Journal of Language and Linguistics. Vol. 5, No. 1, 2017, pp. 25-28. doi: 10.11648/j.ij11.20170501.14

Received: January 11, 2017; Accepted: January 24, 2017; Published: February 22, 2017

\begin{abstract}
The study is to describe the results of back-translation test on the students' translation. The students are those of German Dept., Faculty of Letters, in the State University of Malang. The assessment is on the meaning and form equivalence. The method used is a descriptive method with a qualitative approach. The research includes the analysis and the repeated readings on the data sources, data classification, data analysis, peer group discussion, revision, and conclusion drawing. The data sources are the students' translation on a short story, Das Brot. The data were collected by reading and recording. The analysis was done by comparison method. The result of the analysis shows that most of the students' work have been equivalent to its source text. The unequal realization identified is due to improper lexicon selection and transposition.
\end{abstract}

Keywords: Assessment Technique, Back-Translation, Literary Text

\section{Introduction}

The students of German Literature Department, Faculty of Letters (FS), State University of Malang (UM) are expected to have competence in the field of German language. They are expected to have competence in the field of German language education as a core competency, and the competence in tourism or translation as the additional (JSJ catalog, 2015: 1). Thus, it can be concluded that the acquisition of the German language is the core subject areas that should be mastered. Good German language acquisition in the skills required, facilitate them to professionally teach the German language as well as to work in the field of tourism and or translation.

To support the vision of the department in education and teaching, the students are equipped with the linguistics packaged in the subjects of the German skills. To realize its vision on the field of tourism and translation, they are provided with a subject of "Theory of Translation" ( 2 credits) and translation practices applied in the course Übersetzung (3 credits). By mastering these skills, the students will have the opportunity to develop themselves as candidates for a professional translator, from whom a contribution of good translation product is expected, in addition to the practice of teaching and learning in the relevant institutions.
Many aspects should be considered to produce a good translation due its interdisciplinary nature. Besides good knowledge and skills in Source Language (SL) and Target Language (TL), translation requires other disciplines, including sociolinguistics, cultural knowledge, general knowledge related to the topic/subject matter of the source text. This is in line with the Kautz's (2002: 57) definition of translation:

"Übersetzen ist eine komplexe, funktional bestimmte, plannmäßige, sowohl re-kreative wie auch kreative Tätigkeit im Rahmen der transkulturellen sprachlichen Kommunikation zwischen verschiedensprachigen Partnern".

It means that written translation is a very complex, functional, well-planned, creative and re-creative activity to build an inter-language and cross-cultural communication between the communicants with the different cultural background.

In sum, to produce a good translation, a translator must strive to get the best possible equivalence. This is not an easy job by the differences of meaning system and its realization between the languages involved. Translating the form or the language realization into its similar counterpart often results in a change of meaning and style. The big difference in lexical and grammatical forms selection of one language and another should alert the translator to be careful in transferring 
the meaning in SL to its correspondence in TL. Moreover, for more complex texts, a translator must be strictly careful to deal with meaning, especially with metaphorical or connotative meanings commonly found in literary texts.

Meaning is a major part in translation because the translation is the process of moving the meaning of SL to TL. Most translation scholars put a high priority in the meaning or message elements in their definition of translation. Explicitly, Larson (1984) stated that the core of the translation is the message transfer. The translation process begins with identifying lexicon, grammatical structure, communication situation, and structural context in the SL text. The next stage is analyzing the text to come to its meaning, and then reconstructing the same meaning using the acceptable lexicon and grammatical structure in TL (Larson, 1984: 2).

To measure the success of the translator in the translation process, it requires a series of translation assessments, such as the accuracy test, reasonableness test, readability test, understandability test, consistency test, and back-translation. In this study, the assessment on the student's work is focused on a technique of back-translation. Its main objective is to determine whether the meaning communicated is equivalent to meaning and style of SL (Said, 2002). It is done by having another translator who masters the languages involved to translate a resulted text back into SL and he should not read the ST. This enables the second translator to know what the first translator have communicated in his/her translation. Thus, it does not assess the normality, but the equivalence of meaning and style.

To equip students with the skills and the ability to translate a text, in the course Übersetzung, the students practice translating various types of texts, such as short stories, fairy tales, official letters, recipes, and other text types. Short stories are chosen to determine the students' ability to translate German - Indonesian and vice versa. It is based on the fact that literary text has a variety of translation results, richer than other genres. It is considered to give more freedom to the students in determining the choice of words, especially as it is associated with the transfer of meaning and style. In addition, according to Mahalli, A. et al (2016: 76), literary translation has mostly presupposed a specified notion of "literariness" within which it has been able to mark off it boundaries and to determine its sanctions, methods and approaches to its subjects. All activities in order to measure the success of the translator in the translation process are necessary to build their translation competence.

In fact, translating a literary text is hard task for translators, furthermore for the learners. As Nezam and Pirnajmuddin (2012) state, literary translators have to face double challenges of both rendering the meaning and form. It is due to the fact that form or style is the very soul of an author's expression; to understand and render it as closely as possible it is a must in translating literary text. Thus, the focus of this study is to test the students' translation using back-translation based on the equivalence of meaning and style.

\section{Method}

In line with with the focus of the research, this study employes a qualitative approach, considering the five arguments of Creswell (2007: 35-37). First, the data are words, phrases, clauses, and sentences etc. In this study the data are words, phrases, clauses, and sentences in SL and TL and its back-translation version. Second, researchers act as a key instrument in collecting and analyzing data. Third, it is descriptive and does not test any hypothesis. Fourth, the data were analyzed inductively. Fifth, the meaning and form are the major concern in the analysis.

This study describes phenomena related to the research topic. This is is a content analysis, a technique of research to make valid inferences which can be re-examined based on the context (Krippendorf in Darmiyati, 1993: 2). It applies descriptive method with qualitative approach, aimed at describing analysis results on test of back-translation over translated results carried out by the students. It includes the assessment and repeated reading on the data sources, data classification, data analysis, peer discussions, revision and conclusion. The sources of data in this study is the translation of short story Das Brot.

The data is collected using the technique of reading log. The method used to analyze these data is the comparison method. The purpose is to determine the identity of research object. It is determined by the high levels of correspondences, harmony, conformity, suitability, or similarity by a relevant decisive tool as the parameter (Sudaryanto, 1993: 13).

After the data is grouped in tables, the data recorded in the SL column are compared to their counterpart in the TL column. Then, they are examined at the following aspects:

\subsection{Change of Meaning}

In connection to change of meaning there are two categories. First, the meaning is fixed when the translation results reveal the whole meaning of SL, without any addition (overtranslation) or reduction of information (undertranslation). In other words, there are no changes of meaning including referential meaning, grammatical meaning, sociocultural meaning and contextual meaning. Second, the meaning is changed when there are overtranslations and or undertranslations.

\subsection{Change of Form/Style}

Change of style is the change of a certain style into another, like the change from metaphore to simile or the reverse. Another point to analyze is whether the change of style will lead into the meaning change.

\section{Findings and Discussion}

\subsection{Findings}

As already mentioned earlier, the text used as the data source is the original short story of Das Brot written by 
Wolfgang Borchert (1947) and the translation carried out by the students of 2013 of German department at the state university of Malang, when they had mid-term exam for the course of Übersetzung. The translated text has been then used to assess the equivalence of the meaning and style. In this case it was back-translated to German by the students of the higher level that have taken the course Übersetzung the year before and have never translated this text.

The analysis result shows that among 146 sentences, 126 data meet the corresponding/equivalent criteria and 20 others cannot be considered as equivalent. In terms of their styles/forms, 111 are equivalent, and the rest is not. This general finding is summed in the following table.

Table 1. The Equivalence of Meaning and Style.

\begin{tabular}{lllll}
\hline & Meaning & & Style/Form & \\
\cline { 2 - 5 } & Equivalent & Inequivalent & Equivalent & Inequivalent \\
\hline Number of Sentences & 126 & 20 & 111 & 35 \\
Total & 146 & & 146 & \\
\hline
\end{tabular}

\subsection{Discussion}

In this section, the results will be discussed further. There are three kinds of data based on its source: ST1 refers to the original text, the short story Das Brot, TT is the translation result made by the students in Bahasa Indonesia, and ST2 is a new translation of TT, or the result of back-translation, in German language.

Most of the data resulted from back-translation indicate the correspondence between ST1 and ST2, as shown in the sentence (1) and (2) below:

(1) Ja, ich dachte, wäre es in der Küche. (ST1)

'Ya, aku tadi mengira, suara itu di dapur.' (TT)

('Yes, I thought, that voice in the kitchen.)

$J a$, ich dachte, dass das Geräusch in der Küche wäre. (ST2)

(2) Um halb drei. (ST1)

Setengah tiga ('Half to three.') (TT)

Es war halb drei in Morgendämmerung. (ST2)

With a slightly different arrangement, the word 'es' in ST1 (1) is translated into das Geräusch in ST2. The translators (students) use the word from the word 'suara' ('sound') contained in TT. Meanwhile, the additional information of the phrase in Morgendämmerung (2) does not result overtranslation. The context in a whole paragraph makes it logical to lead into such an understanding. The back translation strengthens the theory stated by Yun (2012) with the statement that back translating is beneficial for fostering learners' consciousness of the lexical, idiomatic, and syntactic differ - ences between their native language and the target language.

The equality of forms/styles between ST1 and ST2 is also evident in the data of structural changes/transposition, provided that the changes do not affect the meaning (Machali, 2007). For example in the sentence (3) below. In the sentence (3), the ST1 which is actually a simple sentence, is reformulated into a compound sentence (ST2) containing a main clause (Hauptsatz) and a subordinate clause (Nebensatz).

(3) Bei Wind klappert sie immer. (ST1)

Kalau kena angin talang itu selalu berderak-derak (TT)

("If the wind gutters, it always crackles")

Windig Wenn es ist, die knarrt Dachrinne. (ST2)
One of the undertranslations or information reduction is seen in the sentences (4) and (5) below. Part of the sentences which are not translated completely will lead into a possible shift in meaning (Larson, 1984). As a result, the original message in the short story Das Brot fails to reach by the target readers.

(4) Sie sah etwas Weißes am Küchenschrank stehen. (ST1)

'Ia melihat bayangan putih berdiri di depan lemari dapur.' (TT)

('He saw a white shadow standing in front of the kitchen cupboard.')

Er sah einen Schatten vor dem Schrank. (BSU2)

(5) Sie sah ihn nicht an, weil sie nicht ertragen konnte, dass er log. (ST1)

'Ia tidak memandang suaminya karena ia tidak tahan bahwa suaminya berbohong.' (TT)

('He did not look at her husband because she could not bear that her husband lied.')

Sie schaut an ihren Mann nicht an. (ST2)

The word Schrank 'lemari' ('cupboard') in ST1 (4) does not necessarily refer to the Küchenschrank 'lemari dapur' ('kitchen cabinet') as it is meant by ST1. This is due to an omission of Küche. Hence, the readers might think that it refers to a wardrobe or another type of cupboard.

The case is even worse in the sentence (5), as the translator eliminates most of the information in the context. ST1 is a compound sentence with two clauses connected by a causality meaning. To this, the translator only makes it into a simple sentence with a single clause. Consequently, the atmosphere which becomes the spirit of the plot is lost-it is not conveyed in the translation.

(6) Das war es, was es so besonders still gemacht hatte; sein Atem fehlte. (ST1)

'Itulah ternyata yang membuat begitu sunyi; suara nafasnya tidak ada.' (TT)

('It is the reason for the silence; his breath has gone')

So, das machte zu still hier. Kein Laut, kein Atem. (ST2)

As mentioned earlier that in back-translation, the normality is not the parameter, but the equivalence of meaning and style. In addition to all the findings, this research identifies data with equivalence in meaning but unequal forms, as clearly seen in (6) above. In terms of meaning, ST2 has met the standards of correspondence, but the expression of kein 
Laut, kein Atem 'tak ada suara, tak ada nafas' (no voice, no breath) contained in ST2 cannot represent the phrase "suara nafasnya tidak ada" (his breath is none) TT.

Improper selection of lexicon can produce a translation which is unequal to the original text. In other words, the mismatch form leads to a discrepancy of meaning, as shown in the sentences (7) and (8) below.

(7) Komm man zu Bett. (ST1)

'Ayo Mas, kita tidur lagi.' (TT) (C'mon Dear. Let's sleep again)

Wir schlafen noch. (ST2)

(8) Ihre nackten Füße platschten auf den Fußboden. (ST1)

'Dengan bertelanjang kaki langkah mereka bersuara di atas ubin.' (TT)

'With barefoot their steps echoed over the tiles.'

Sie sprechen über die Fliesse barfu $\beta$. (ST2)

The form/style in TT (7) is an imperative form as it is in ST1. Meanwhile, in the sentence of ST2, it is transformed into a declarative sentence, Wir schlafen noch, meaning 'we are still sleeping'. This surely doesn't contain the same meaning as 'Come Dear, we sleep again'. The use of noch 'still' is not appropriate for the sentence and makes it a statement, which is different from the original, an imperative.

The similar mismatch also occurs in the sentence (8). The meaning and the form of ST2 are not equivalent to TT. The sentence Sie sprechen über die Fliesse barfu $\beta$ means 'Mereka berbicara tentang lantai dengan bertelanjang kaki', ('They are talking about the floor with bare feet'). The meaning is very different from 'Dengan bertelanjang kaki langkah mereka bersuara di atas ubin' (in barefoot, their steps were heard over the tiles). The sentences (7) and (8) represent the data of unequal meaning and form between ST1 and ST2. Both kind of translations, which do not maintain the original style, do not correspond with the Nezam's statement (2012) that the fidelity to the style of a writer is an imperative.

\section{Conclusion and Suggestion}

\subsection{Conclusion}

Back-translation technique on the translation of Das Brot has produced a translation which is equivalent to the ST. Only few indicate unequal realization in form and meaning. This suggests that students have been relatively successful in the translation process. The discrepancies are identified either in meaning or in form, and in both.

The unequal translation is mostly generated from the improper selection of the lexicon, which results in different meaning. In addition, the different forms of the sentence affect adversely the translation. Some transposition in the translation has changed the message of the original.

\subsection{Suggestion}

Based on the results of this study, two suggestions are proposed:

First, to improve the quality of student translation, especially that of literary genre texts, it needs more practices for the students in the subject Übersetzung. Additionally in Translation Theory course, the students should be provided with more theories on the procedures and techniques of literary translation.

Secondly, for other researchers interested in translation, they are advised to conduct various tests over the works of translation, both literary and non-literary, especially those have been published. This is to give feedback for the professional translators in doing their jobs, and in turn it will lead into more translated materials with high quality.

\section{References}

[1] Darmiyati, Zuchdi. (1993). Seri Metodologi Penelitian: Panduan Penelitian Analisis Konten. Yogjakarta: Lembaga Penelitian IKIP Yogjakarta.

[2] Kautz, U. (2002). Handbuch der Didaktik des Übersetzens und Dolmetschens. München: Iudicium.

[3] Larson, Mildred A. (1984). Meaning-Based Translation. Lanham: University Press of America.

[4] Machali, Rochayah. 2007. Pedoman bagi Penerjemah. Jakarta: Grasindo.

[5] Mahalli, A., Valipour, V., Mahdavi, M. (2016). Translation of Ellipsis as a Stylistic Feature: Hemingway's a Farewell to Arms and its Persian Translation. International Journal of English Language \& Translation Studies. 4 (3). 75-80. Retrieved from www.eltsjounal.org.

[6] Nababan, M. Rudolf. 2003. Teori Menerjemah Bahasa Inggris. Yogyakarta: Pustaka Pelajar.

[7] Nezam, Arezou, and Pirnajmuddin, Hossein. (2012). Translation of Ellipsis as a Stylistic Feature: Hemingway's The Old Man and the Sea and its Persian Translation. Journal of Language Teaching and Research, Vol. 3, No. 6. 1250-1257.

[8] Said, Mashadi. 2002. Menilai Terjemah. Jurnal Ilmiah Sastra Bahasa vol. 7 no. 2 (Dec. 2002), page 56.

[9] Suryawinata, Zuchridin \& Sugeng Hariyanto. 2003. Translation: Bahasan Teori dan Penuntun Praktis Menerjemahkan. Yogyakarta: Kanisius.

[10] Yun Zhang and Cun Gao. 2014. Back Translating: An Integrated Approach to Focus Learners'Attention on Their L2 Knowledge Gaps. English Teaching Forum. Number 1.2014. Retrieved from https://americanenglish.state.gov/files/ae/resource_files/52_1_ 6_zhang_gao.pdf 